\title{
Pengukuran Technological Pedagogical Content Knowledge untuk Guru Matematika SMA di Daerah Tertinggal
}

\author{
Nena Restiana ${ }^{1^{*}}$ dan Heni Pujiastuti ${ }^{2}$ \\ Mathematics Education Department, Universitas Sultan Agung Tirtayasa \\ Jalan Raya Jakarta Km 4 Pakupatan, Serang, 42118, Indonesia \\ ${ }^{1 *}$ resti.nena@gmail.com \\ 2henipujiastuti@untirta.ac.id
}

Artikel diterima: 20-11-2018, direvisi: 21-11-2018, diterbitkan: 31-01-2019

\begin{abstract}
Abstrak
Teknologi informasi dan komunikasi (TIK) telah berkembang begitu pesat dalam satu dekade terakhir ini. Perkembangan tersebut mengakibatkan banyak perubahan hampir di segala bidang, tak terkecuali bidang pendidikan. Pemanfaatan TIK dalam bidang pendidikan, salah satunya dibutuhkan sebagai upaya efisiensi dan efektifitas proses pembelajaran. Akan tetapi, ada banyak hambatan yang dihadapi dalam penerapannya, diantaranya kurangnya pemahaman guru terhadap teknologi. Penelitian ini berupaya mendeskripsikan pemahaman guru tersebut, ditinjau dari kerangka kerja TPACK (Technological, Pedagogical and Content Knowledge). Penelitian ini dilakukan terhadap 24 guru matematika SMA di daerah tertinggal di propinsi Banten. Penelitian ini menggunakan pendekatan deskriptif kuantitatif. Pengaruh usia, jenis kelamin, dan lama mengajar guru terhadap konstruksi TPACK dianalisis menggunakan analysis of variance (ANOVA). Hasil penelitian ini menunjukkan bahwa: 1) Di antara komponen TPACK, hanya TK (Technological Knowledge) dan TCK (Technological Content Knowledge) yang berkorelasi signifikan terhadap pengetahuan TPACK guru; 2) Persepsi guru terhadap TPACK dipengaruhi secara signifikan oleh faktor usia, sedangkan jenis kelamin dan lama mengajar guru tidak berpengaruh signifikan.

Kata Kunci: Jenis kelamin, lama mengajar, matematika, TIK, TPACK, usia.

\section{Measuring Technological Pedagogical Content Knowledge for Mathematic Teacher at Senior High School in Underdeveloped Region}

Abstract

Information and Communication Technology (ICT) has growth for the last decade. Consequently, it influences on all areas include education. Education needs ICT to make learning process more effective and dynamic. However, there are many barriers to implement of ICT. One of barriers is about teachers' perception on ICT. This research describes teachers' perception on ICT teachers using TPACK framework. This research conducted at senior high school mathematics teachers in underdeveloped region of Banten. Furthermore, the relative impact of age, gender, duration of teaching on the TPACK is analysed using analysis of variance (ANOVA). The results of this research are: among the TPACK component, only TK (Technological Knowledge) and TCK (technological content knowledge) were significant correlation with teacher's TPACK perception; 2) variable of age is significant influenced on teachers' TPACK perceptions, while the gender and duration of teaching are not significant. Keyword: age, gender, duration of teaching, ICT, TPACK, mathematic.
\end{abstract}




\section{Pendahuluan}

Kurikulum, pengajaran

dan pembelajaran matematika memerlukan perubahan yang sesuai dengan kebutuhan dan perkembangan teknologi informasi dan komunikasi (TIK) (Haapasalo, 2017). TIK diharapkan dapat memberikan pengaruh positif dalam proses pembelajaran.

Keong, Horani and Daniel (2005) menyatakan bahwa pembelajaran matematika dengan menggunakan TIK dapat membuat pembelajaran lebih efektif dan memberikan peningkatan kemampuan siswa pada pemahaman konsep dasar, namun pada tahap implementasi masih ada kendala guru dalam melakukan itegrasi TIK ke dalam proses pembelajaran.

Kendala implementasi tersebut akan lebih dirasakan oleh guru yang berada daerah tertinggal, dimana daerah tersebut memiliki banyak keterbatasan dibandingkan dengan daerah lain. Diantara keterbatasan tersebut adalah sumber daya manusia dengan ketrampilan yang rendah (Peraturan Presiden Nomor 131/2005 Tahun 2015).

Jika keterbatasan tersebut tidak segera dilakukan evaluasi dan perbaikan, maka akan berdampak pada kualitas pendidikan. Dengan demikian, diperlukan evaluasi sumber daya manusia dalam hal ini adalah guru sebagaimana intruksi menteri melalui Peraturan Menteri Desa, Pembangunan Daerah Tertinggal dan Transmigrasi Republik Indonesia Nomor 6 Tahun 2015.
Salah satu upaya yang dapat dilakukan adalah dengan mengetahui kemampuan guru terhadap teknologi, konten dan cara mengajar dalam pembelajaran yang dilakukan. Dengan demikian, guru diharapkan menjadi lebih kreatif (Afriansyah, 2017) dan professional dengan kompetensi yang dimiliki (Tarusu, 2018).

Metode pengukuran pengetahuan guru dalam mengintegrasikan TIK dapat menggunakan kerangka Technological, Pedagogical, Content, Knowledge (TPACK). Koehler and Mishra (2009) menjelaskan bahwa TPACK merupakan basis integrasi antara komponen content knowledge (CK), pedagogical knowledge (PK), technological knowledge (TK).

Tujuh komponen TPACK yaitu CK, PK, TK, TPK (technological pedagogical knowledge), TCK (technological content knowledge), PCK (pendagogical content knowledge) dan TPACK (technological pedagogical content knowledge), dimana Chai, Koh and Tsai (2011) menyatakan bahwa 7 komponen tersebut mempunyai hubungan positif dan signifikan.

Penelitian menggunakan kerangka TPACK sudah dilakukan untuk mengukur penggunaan TIK dalam pembelajaran mata pelajaran matematika (Chai et al., 2011; Jang \& Tsai, 2012; Liang \& Luo, 2016). Penelitian tentang pemahaman terhadap TPACK juga dikaitkan dengan usia dan lama mengajar (Lin et al., 2013; Chuang and $\mathrm{Ho}, 2011$ ) atau dengan jenis kelamin ( Liu et al., 2015; Lin et al., 2013) dimana 
ketiga faktor tersebut berpengaruh terhadap beberapa komponen TPACK.

Berdasarkan pada studi literatur yang dilakukan, banyak studi yang membahas tentang PCK, salah satunya adalah Irfan dkk (2018) yang menganalisis PCK pada mahasiswa pendidikan matematika. Akan tetapi, masih sedikit penelitian yang membahas pengukuran TPACK untuk daerah tertinggal. Dengan demikian, penelitian ini akan mengisi kekurangan tersebut dalam rangka mengukur kemampuan TIK guru matematika di daerah tertinggal pada aspek pembelajaran dan mendefinisikan pengaruh faktor usia, lamanya mengajar dan jenis kelamin terhadap pengetahuan TPACK.

Fokus penelitian ini adalah pada guru matematika tingkat SMA, karena SMA dinilai sebagai perwujudan kebijakan wajib belajar 12 tahun dari pemerintah daerah Banten melalui Peraturan Daerah Propinsi Banten Nomor 7 Tahun 2012.

Hasil penelitian ini adalah gambaran penguasaan TPACK guru matematika di daerah tertinggal dan faktor yang mempengaruhinya dari faktor usia, jenis kelamin dan lama mengajar. Dengan demikian, hasil penelitian ini dapat menjadi masukan bagi dinas pendidikan daerah tertinggal untuk melakukan peningkatan kemampuan TPACK guru matematika.

\section{Metode}

Penelitian ini adalah jenis penelitian deskriptif kuantitatif yang Mosharafa: Jumal Pendidikan Matematika Volume 8, Nomor 1, Januari 2019 Copyright $\odot 2019$ Mosharafa: Jurnal Pendidikan Matematika menggambarkan hubungan antara pengetahuan TPACK guru terhadap variabel usia, jenis kelamin dan lama mengajar.

Dalam rangka ekplorasi persepsi guru terhadap TPACK, dilakukan pemilihan 24 sampel dengan metode random sampling terhadap guru matematika SMA di Kabupaten Lebak di propinsi Banten meliputi faktor usia (U), jenis kelamin (JK), dan lamanya mengajar (LM). Responden terdiri dari perempuan (58,3\%) dan Lakilaki (41,7\%). Semua responden dalam penelitian ini diberikan informasi melalui kuesioner online dan kuesioner langsung untuk mengisi tentang persepsi guru terhadap TPACK.

Penelitian ini mengukur teknologi, pedagogi, dan pengetahuan pembelajaran guru menggunakan kerangka kuisioner TPACK dari Schmidt, Baran, Ann, Mishra, \& Koehler (2009) yang divalidasi oleh Zelkowski, Gleason, Cox, Bismarck (2013) menjadi 62 item terdiri dari 8 item TK, 8 item CK, 8 item PK, 7 item PCK, 7 item TPK, 12 item TCK, dan 12 item TPACK.

Kerangka kerja TPACK dibangun berdasarkan deskripsi PCM Shulman untuk menggambarkan bagaimana pemahaman guru tentang teknologi pendidikan dan PCK berinteraksi satu sama lain untuk menghasilkan pengajaran yang efektif dengan teknologi. TPACK yang digambarkan di sini telah berkembang dari waktu ke waktu dan melalui serangkaian publikasi, dengan deskripsi paling lengkap tentang kerangka kerja.Dalam model ini (lihat Gambar 1), ada tiga komponen 
utama pengetahuan guru: content, pedagogical, dan technological. Interaksi antara badan pengetahuan tersebut PCK, TCK, TPK, dan TPACK.

Definisi komponen TPACK (M J Koehler, ishra, Akcaoglu, \& Rosenberg, 2006; Chuang \& Ho, 2011) adalah:

\section{Technological Knowledge (TK):} bagaimana penggunaan berbagai teknologi dalam pembelajaran baik berupa perangkat lunak maupun perangkat keras seperti presenter dokumen dan proyek, dan teknologi lainnya dalam konteks pendidikan.

2. Content knowledge (CK): berbicara mengenai pengetahuan tentang pokok bahasan aktual dan domain konten tertentu seperti matematika dan sains yang harus diketahui dan familiar oleh guru agar bisa diajar.

3. Pedagogical knowledge (PK): PK menggambarkan metode dan proses pembelajaran manajemen kelas, evaluasi, pengembangan rencana pembelajaran, dan pembelajaran siswa.

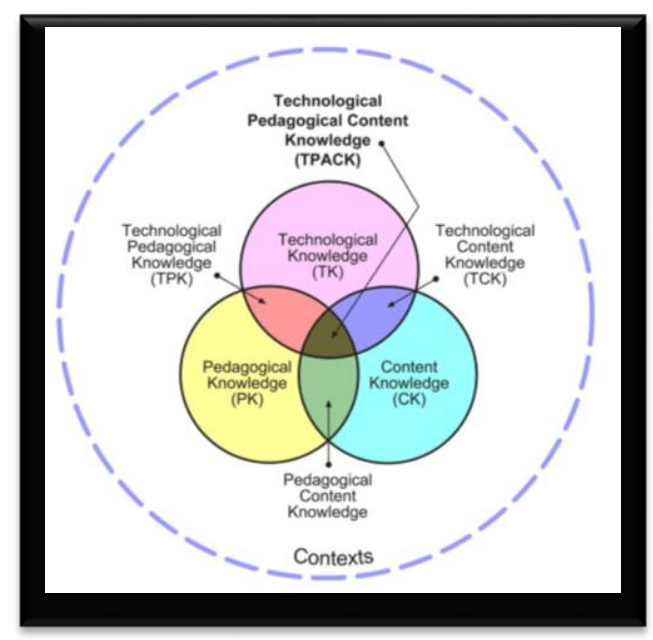

Gambar 1. Kerangka kerja TPACK.
4. Pedagogical content knowledge (PCK): PCK berbeda tergantung konten yang diajar. PCK merupakan penggabungan antara konten dan pedagogis yang bertujuan untuk pengembangan praktik pembelajaran konten yang lebih baik.

5. Technological content knowledge (TCK): Pengetahuan tentang bagaimana teknologi dapat menciptakan representasi baru untuk konten tertentu dan dapat mempengaruhi praktik dan pengetahuan tentang disiplin tertentu. Ini menunjukkan bahwa para guru memahami bahwa dengan memanfaatkan teknologi tertentu dalam pengajaran dan pembelajaran, mereka dapat mengubah cara peserta didik berlatih dan memahami konsep di area konten tertentu.

6. Technological pedagogical knowledge (TPK): Pengetahuan tentang bagaimana berbagai teknologi dapat digunakan dalam pengajaran dan pemahaman bahwa penggunaan teknologi dapat mengubah cara guru mengajar. Termasuk juga kemampuan dan keterbatasan pedagogis dari berbagai alat teknologi.

7. Technological pedagogical content knowledge (TPACK): Pengetahuan tentang interaksi yang kompleks antara tiga komponen pengetahuan dasar (CK, PK, TK) yang dimiliki seorang guru saat mengajarkan konten menggunakan metode dan teknologi pedagogis yang sesuai. TPACK adalah dasar pengajaran yang efektif dengan teknologi.

Mosharafa: Jurnal Pendidikan Matematika Volume 8, Nomor 1, Januari 2019 Copyright $\odot 2019$ Mosharafa: Jurnal Pendidikan Matematika 
Skala yang digunakan dalam penelitian adalah skala likert dari 1-5 (1 = sangat tidak setuju sampai 5 = sangat setuju).

Hasil kuisioner TPACK terlebih dahulu dilakukan validasi faktor dari masingmasing komponen TPACK dengan menggunakan salah satu metode Exploratory Factor Analysis yaitu Principal Component Analysis (PCA). Analisis ini mencoba menemukan hubungan antar sejumlah variabel-variabel yang saling bebas satu sama lain sehingga dapat dibuat satu atau beberapa set variabel yang lebih sedikit dari jumlah variabel awal. Dalam hal ini variabel yang memiliki korelasi terbesar akan berkelompok membentuk suatu set variabel (membentuk satu faktor).

Dalam analisis faktor, yang dipertahankan adalah dengan kriteria eigenvalue lebih besar dari 1. Analisis faktor digunakan untuk mengetahui struktur akhir TPACK. Profilisasi TPACK dilakukan dengan cara perankingan dari hasil perhitungan rata-rata masing-masing skala.

Penelitian ini akan melihat korelasi antar komponent TPACK yang terbentuk dengan teknik korelasi Rank Spearman. Korelasi Rank Spearman digunakan untuk mengetahui hubungan antara variabel bebas dan variabel tergantung yang berskala ordinal. Korelasi dapat menghasilkan angka positif (+) atau negatif (-). Jika korelasi menghasilkan angka positif maka hubungan kedua variable bersifat searah. Jika korelasi menghasilkana tanda negatif maka hubungan kedua variable bersifat tidak searah. Kriterianya sebagai berikut:

a. Besar kecilnya angka korelasi menentukan kuat atau lemahnya hubungan kedua variable. Patokan angkanya adalah sebagai berikut:

Tabel 1.

Angka Korelasi

\begin{tabular}{ll}
\hline Nilai & \multicolumn{1}{c}{ Korelasi } \\
\hline $0-0,25$ & Lemah \\
\hline$>0,25-0,5$ & Moderat \\
\hline$>0,5-0,75$ & Kuat \\
\hline$>0,75-1$ & Sangat Kuat \\
\hline
\end{tabular}

b. Signifikasi hubungan antara dua variable dapat analisis dengan ketentuan sebagai berikut: Jika probabilitas < 0,05 maka hubungan kedua variable signifikan. Jika probabilitas $>0,05$ maka hubungan kedua variable tidak signifikan.

Dalam analisis faktor dilakukan rotasi faktor utama. Langkah ini dimaksudkan untuk mendapatkan harga maksimum masing-masing variabel terhadap setiap komponen utama. Rotasi dilakukan dengan memutar sumbu-sumbu faktor secara orthogonal. Hal ini dilakukan karena komponen utama yang dihasilkan pada langkah sebelumnya belum merupakan solusi akhir karena masih memuat variable yang sama terhadap setiap komponen utama dengan nilai loading yang bervariasi sehingga menyulitkan interpretasi terhadapnya. Rotasi matrik loading akan memudahkan untuk mengidentifikasi karena besarnya faktor loading akan menjadi lebih ekstrim yaitu akan sangat besar atau sangat kecil terhadap setiap

\section{Mosharafa: Jurnal Pendidikan Matematika}


komponen utama. Seperti diuraikan diatas bahwa loading faktor menunjukkan besarnya kontribusi suatu faktor terhadap suatu komponen utama. Bobot faktor yang tinggi menunjukkan besarnya pengaruh suatu faktor initial terhadap suatu komponen utama. Namun demikian untuk membatasi banyaknya faktor yang muncul dalam setiap komponen utama maka dalam penelitian ini digunakan criteria bahwa nilai bobot faktor harus lebih besar atau sama dengan 0.5 .

Selanjutnya dilakukan investigasi hubungan antara faktor usia, jenis kelamin, dan lama mengajar terhadap persepsi TPACK (gambar 2) dengan menggunakan Analysis of Variance (ANOVA) t-test. Kriteria jika $t_{\text {hitung }}>t_{\text {tabel }}$ maka faktor tersebut dikatakan berpengaruh signifikan untuk variabel yang ditentukan.

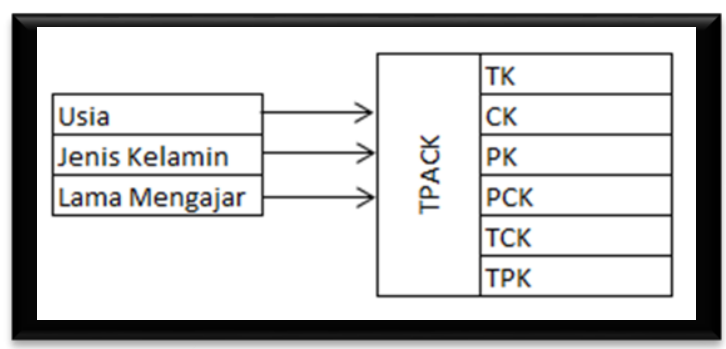

Gambar 1. Kerangka Penelitian.

\section{Hasil dan Pembahasan}

Terkait dengan teknologi yang digunakan oleh guru matematika SMA di daerah tertinggal di Banten mayoritas masih menggunakan papan tulis $(54,2 \%)$ sebagai media pembelajaran, sedangkan lainnya menggunakan aplikasi powerpoint $(33,3 \%)$ dan aplikasi interaktif (12,5\%).

Untuk Hasil validasi dengan menggunakan analisis faktor, dapat dilihat di table 1. dari analisis varimax-rotated matrix utama dilakukan untuk mengidentifikasi apakah item dalam skala bisa dikelompokkan dengan faktor-faktor independen dan bermakna. Sebuah analisis komponen utama ini berkaitan dengan bagaimana variabel tertentu akan memberikan kontribusi untuk komponen serta dengan pembentukan komponen yang ada dalam data (Field, 2009). Sedangkan batas bawah loading faktor item diterima menjadi 0,40 (Field, 2009). Proses ini didapatkan bahwa semua item TPACK memberikan kontribusi pada pembentukan komponen TPACK.

Tabel 2.

Rotated Component Matrix

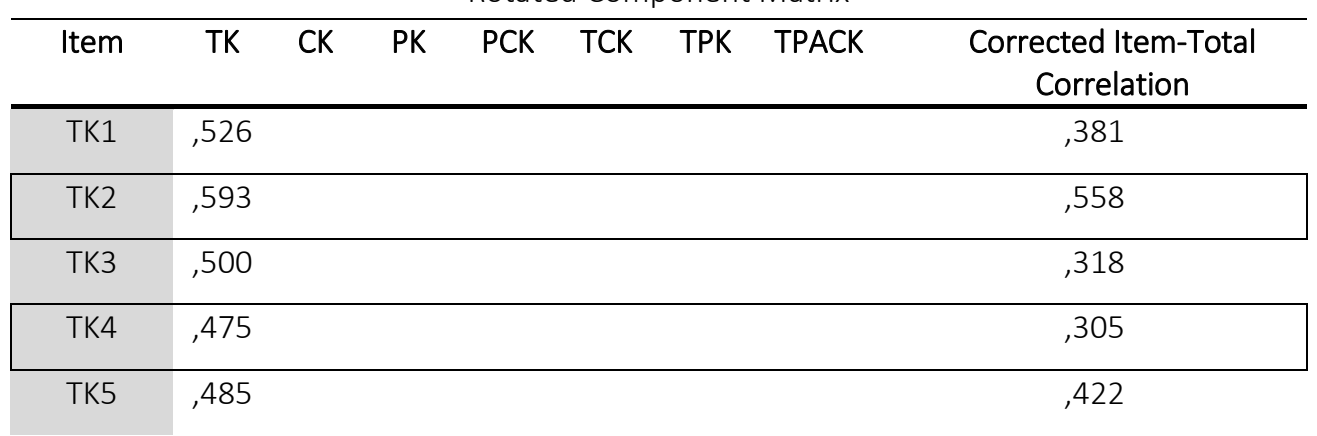




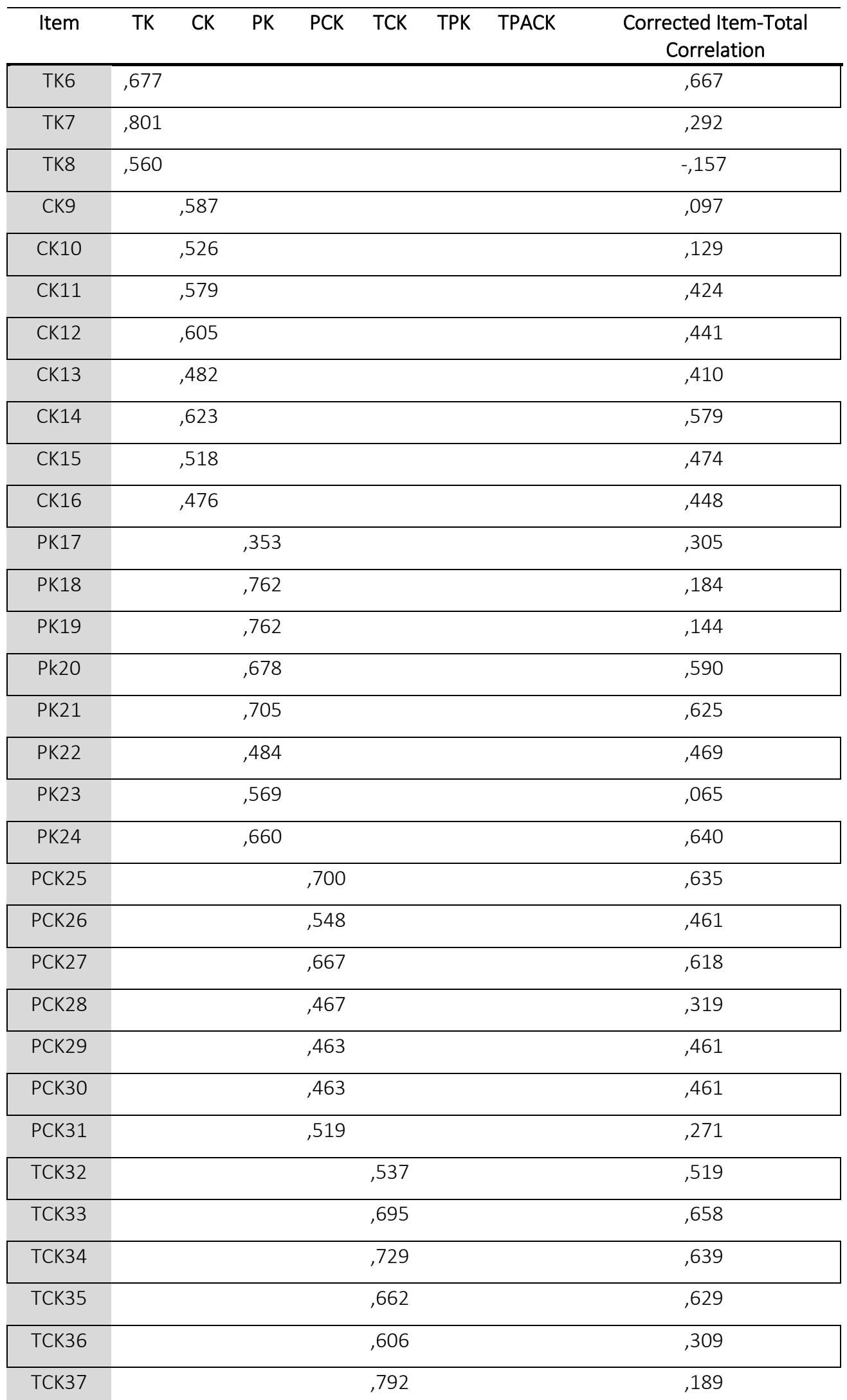




\begin{tabular}{|c|c|c|c|c|c|c|c|c|}
\hline Item & TK & CK & PK & PCK & TCK & TPK & TPACK & $\begin{array}{c}\text { Corrected Item-Total } \\
\text { Correlation }\end{array}$ \\
\hline TCK38 & & & & & ,636 & & & ,532 \\
\hline TPK39 & & & & & & ,613 & & 145 \\
\hline TPK40 & & & & & & ,658 & & ,530 \\
\hline TPK41 & & & & & & ,745 & & ,661 \\
\hline TPK42 & & & & & & ,733 & & ,664 \\
\hline TPK43 & & & & & & ,414 & & ,005 \\
\hline TPK44 & & & & & & ,463 & & 285 \\
\hline TPK45 & & & & & & ,462 & & ,304 \\
\hline TPK46 & & & & & & ,550 & & ,345 \\
\hline TPK47 & & & & & & ,421 & & 304 \\
\hline TPK48 & & & & & & ,657 & & ,610 \\
\hline TPK49 & & & & & & ,580 & & ,500 \\
\hline TPK50 & & & & & & ,734 & & 677 \\
\hline TPACK51 & & & & & & & ,740 & 188 \\
\hline TPACK52 & & & & & & & ,530 & 271 \\
\hline TPACK53 & & & & & & & ,616 & 271 \\
\hline TPACK54 & & & & & & & ,615 & 205 \\
\hline TPACK55 & & & & & & & ,683 & ,098 \\
\hline TPACK56 & & & & & & & ,558 & ,559 \\
\hline TPACK57 & & & & & & & ,536 & ,525 \\
\hline TPACK58 & & & & & & & ,816 & ,757 \\
\hline TPACK59 & & & & & & & ,604 & 274 \\
\hline TPACK60 & & & & & & & ,550 & ,437 \\
\hline TPACK61 & & & & & & & ,477 & ,496 \\
\hline TPACK62 & & & & & & & ,360 & ,394 \\
\hline
\end{tabular}

Hasil korelasi antar komponen TPACK didapatkan bahwa ada korelasi positif kuat CK-PCK $(r=0,608)$, TK-TPK $(r=0,519)$, ), CKTPK $(r=0,576)$, PCK-TPK $(r=0,715)$, TK-TCK $(r=0,577)$, TPK-TCK $(r=0,609)$, TK-TPACK $(r=0,541)$, TCK-TPACK $(r=0,656)$ sesuai dengan table 2 Korelasi Antar Komponen
TPACK. Untuk komponen yang berkorelasi positif moderat adalah TK-PK $(r=0,443)$, CK-PK $(r=0,323)$, TK-PCK $(r=0,291)$, PK-PCK $(r=0,489), \quad P K-T P K(r=0,366), \quad$ PK-TCK $(r=0,311)$, PCK-TCK $(r=0,340)$, PK-TPACK $(r=0,326), \quad$ TPK-TPACK $\quad(r=0,410)$. Sedangkan untuk yang lain berkorelasi 
lemah dan negatif. Dengan demikian, TK dan TCK menjadi komponen yang berpengaruh signifikan terhadap persepsi
TPACK guru matematika, hasil ini sama dengan penelitian sebelumnya oleh Chai, Koh and Tsai (2011).

Tabel 3.

Hasil Korelasi Antar Komponen TPACK

\begin{tabular}{|c|c|c|c|c|c|c|c|c|}
\hline & & TK & CK & PK & PCK & TPK & TCK & TPACK \\
\hline \multirow{3}{*}{ TK } & Pearson Correlation & 1 & 199 & $.443^{*}$ & 291 & $.519^{* *}$ & $.577^{* *}$ & $.541^{* *}$ \\
\hline & Sig. (2-tailed) & & ,352 & 030 & , 168 & 009 & 003 & ,006 \\
\hline & $\mathrm{N}$ & & 24 & 24 & 24 & 24 & 24 & 24 \\
\hline \multirow{3}{*}{ CK } & Pearson Correlation & & 1 & ,323 & $.608^{* *}$ & $.576^{* *}$ & 182 & ,007 \\
\hline & Sig. (2-tailed) & & & 123 & 002 & ,003 & ,395 & ,976 \\
\hline & $N$ & & & 24 & 24 & 24 & 24 & 24 \\
\hline \multirow{3}{*}{ PK } & Pearson Correlation & & & 1 & $.489^{*}$ & ,366 & ,311 & 326 \\
\hline & Sig. (2-tailed) & & & & 015 & ,079 & 140 & 121 \\
\hline & N & & & & 24 & 24 & 24 & 24 \\
\hline \multirow{3}{*}{ PCK } & Pearson Correlation & & & & 1 & $.715^{* *}$ & 340 & 151 \\
\hline & Sig. (2-tailed) & & & & & 000 & 104 & ,482 \\
\hline & $N$ & & & & & 24 & 24 & 24 \\
\hline \multirow{3}{*}{ TPK } & Pearson Correlation & & & & & 1 & $.609^{* *}$ & $.410^{*}$ \\
\hline & Sig. (2-tailed) & & & & & & ,002 & ,047 \\
\hline & $\mathrm{N}$ & & & & & & 24 & 24 \\
\hline \multirow{3}{*}{ TCK } & Pearson Correlation & & & & & & 1 & $.656^{* *}$ \\
\hline & Sig. (2-tailed) & & & & & & & ,000 \\
\hline & $N$ & & & & & & & 24 \\
\hline \multirow{3}{*}{ TPACK } & Pearson Correlation & & & & & & & 1 \\
\hline & Sig. (2-tailed) & & & & & & & \\
\hline & $N$ & & & & & & & \\
\hline
\end{tabular}

Analisis pengaruh dari faktor usia $(U)$, lama mengajar (LM) dan jenis kelamin (JK) terhadap persepsi TPACK dengan menggunakan ANOVA pada taraf siginifikansi $5 \%$ dan $\mathrm{df}=24-1$ didapat $\mathrm{t}_{\text {tabel }}=$ 1,713 , dan thitung sebagaimana pada table 4. Persepsi Guru terhadap TPACK ditinjau dari Usia, Lama Mengajar dan Jenis Kelamin. Dengan demikian, dapat disimpulkan bahwa faktor usia

\section{Mosharafa: Jurnal Pendidikan Matematika}

Volume 8, Nomor 1, Januari 2019

Copyright @ 2019 Mosharafa: Jurnal Pendidikan Matematika berpengaruh terhadap persepsi TPACK, hal ini sesuai dengan penelitian sebelumnya yang dilakukan oleh (Lin et al., 2013; Chuang and Ho, 2011). Adapun faktor jenis kelamin tidak ada pengaruh terhadap persepsi TPACK, hasil ini sebagaimana penelitian Koh \& Chai (2011), begitu juga untuk lama mengajar tidak ada pengaruh terhadap persepsi TPACK. 
Faktor usia, jenis kelamin dan lama mengajar menjadi faktor yang perlu dilakukan studi lanjut terkait dengan pengaruhnya terhadap persepsi TPACK guru. Penelitian faktor lain juga dapat dipertimbangkan seperti kompetensi teknologi, interaksi dengan teknologi maupun metode pembelajaran.
Komponen TPACK dan korelasi yang terjadi antar komponen pada daerah tertinggal, tidak ada perbedaan dengan daerah lain, begitu juga dengan faktofaktor yang mempegaruhi komponen TPACK.

Tabel 4.

Persepsi Guru terhadap TPACK ditinjau dari Usia, Lama Mengajar dan Jenis Kelamin

\begin{tabular}{llll}
\hline Komponen & Faktor & S.D & $\mathrm{t}$-value \\
\hline TPACK & Usia & 1,03 & 2,043 \\
\hline TPACK & Jenis kelamin & 0,50 & $-0,161$ \\
\hline TPACK & Lama mengajar & 0,86 & $-1,332$
\end{tabular}

\section{Penutup}

Penelitian evaluasi TPACK terhadap guru SMA di daerah tertinggal di Banten didapatkan tujuh komponen TPACK. Berdasarkan item TPACK tersebut, komponen TK dan TCK berpengaruh positif kuat terhadap persepsi TPACK guru matematika. Analisis dari faktor usia, lamanya mengajar dan jenis kelamin didapatkan bahwa, usia berpengaruh signifikan terhadap persepsi TPACK guru matematika, sedangkan faktor jenis kelamin dan lamanya mengajar tidak ada pengaruh signifikan terhadap kelima komponen persepsi TPACK guru.

\section{Daftar Pustaka}

Afriansyah, E. A. (2017). Problem Posing sebagai Kemampuan Matematis. Mosharafa: Jurnal Pendidikan Matematika, 6(1), 163-180.
Chai, C. S., Koh, J. H. L., \& Tsai, C.-C. (2011). Exploring the factor structure of the constructs of Technological, Pedagogical, Content Knowledge (TPACK). The Asia-Pacific Education Researcher, 20(3), 595-603.

Chai, S. C., Koh, J. H. L., Tsai, C., \& Tan, L. L. W. (2011). Computers \& Education Modeling primary school pre-service teachers' Technological Pedagogical Content Knowledge (TPACK) for meaningful learning with information and communication technology (ICT). Computers \& Education, 57(1), 11841193.

https://doi.org/10.1016/j.compedu.20 11.01 .007

Chuang, H.-H., \& Ho, C.-J. (2011). An investigation of early childhood teachers' technological pedagogical content knowledge (TPACK) in Taiwan. Journal of Kirsehir Education Faculty, 
12(2), 99-117. Retrieved from http://www.doaj.org/doaj?func=abstr act\&id=782294\&recNo=6\&toc $=1 \&$ uil anguage $=e n$

Field, A. (2009). Discovering Statistics Using SPSS Third Edition. SAGE Publications Ltd (Vol. 622). https://doi.org/10.1007/978-0-38768969-2 13

Haapasalo, L. (2017). Adapting mathematics education to the needs of Adapting Mathematics Education to the Needs of ICT. The Electronic Journal of Mathematics and Technology, 1(1), 1-10.

Irfan, A., Anzora, \& Fuadi, T. M. (2018). Analisis Pedagogical Content Knowledge Mahasiswa Calon Guru Pada Program Studi Pendidikan Matematika. Mosharafa: Jurnal Pendidikan Matematika, 7(2), 239250.

Jang, S., \& Tsai, M. (2012). Computers \& Education Exploring the TPACK of Taiwanese elementary mathematics and science teachers with respect to use of interactive whiteboards. Computers \& Education, 59(2), 327338.

https://doi.org/10.1016/j.compedu.20 12.02.003

Keong, C. C., Horani, S., \& Daniel, J. (2005). A Study on the Use of ICT in Mathematics Teaching. Malaysian Online Journal of Instructional Technology (MOJIT), 2(3), 43-51.

Koehler, M. J., \& Mishra, P. (2009). What Is Technological Pedagogical Content
Knowledge? Contemporary Issues in Technology and Teacher Education, 9(1), 60-70.

Koehler, M. J., Mishra, P., Akcaoglu, M., \& Rosenberg, J. M. (2006). The Technological Pedagogical Content Knowledge Framework for Teachers and Teacher Educators. In ICT Integrated Teacher Education: A Resource Book (pp. 2-7).

Koh, J. H. L., \& Chai, C. S. (2011). Modeling pre-service teachers' technological pedagogical content knowledge (TPACK) perceptions: The influence of demographic factors and TPACK constructs. Proceedings of Australian Society for Computers in Learning in Tertiary Education Annual Conference 2011, 2011, 735-746. https://doi.org/10.1111/j.1365-

2729.2010.00372.x

Liang, X., \& Luo, J. (2016). Micro-lesson Design: A Typical Learning Activity to Develop Pre-service Mathematics Teachers' TPACK Framework. In Proceedings - 2015 International Conference of Educational Innovation Through Technology, EITT 2015 (Vol. 2, pp. 259-263). https://doi.org/10.1109/EITT.2015.61 Lin, T., Tsai, C., Chai, C. S., \& Lee, M. (2013). Identifying Science Teachers' Perceptions of Technological Pedagogical and Content Knowledge (TPACK). J Sci Educ Technol, 22, 325336. https://doi.org/10.1007/s10956012-9396-6 
Peraturan Daerah Propinsi Banten Nomor

7 Tahun 2012, Unknown § (2012). Retrieved from http://www.dt.co.kr/contents.html?ar ticle_no=2012071302010531749001

Peraturan Menteri Desa, Pembangunan Daerah Tertinggal, dan Transmigrasi Republik Indonesia Nomor 6 Tahun 2015 Tentang Organisasi dan Tata Kerja Kementrian Desa, Pembanguna Daerah Tertinggal, dan Transmigrasi (2015).

Peraturan Presiden Nomor 131/2005 Tahun 2015.

Schmidt, D. A., Baran, E., Ann, D., Mishra, P., \& Koehler, M. J. (2009). Journal of Research on Technology in Education Technological Pedagogical Content Knowledge (TPACK), (November 2014), $37-41$. https://doi.org/10.1080/15391523.20 09.10782544

Tarusu, D. T. (2018). Kemampuan Pedagogik Matematika SD Pada Mahasiswa PGSD UNIMA. Mosharafa: Jurnal Pendidikan Matematika, 7(2), 251-262.

Zelkowski, J., Gleason, J., Cox, D. C., \& Bismarck, S. (2013). Developing and validating a reliable TPACK instrument for secondary mathematics preservice teachers. Journal of Research on Technology in Education, 46(2), 173206.

https://doi.org/10.1080/15391523.20 13.10782618

\section{Riwayat Hidup PENULIS}

Nena Restiana, S. Kom.

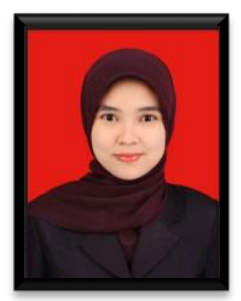

Lahir di Serang, 1 Juli 1988. Mahasiswa Pasca Sarjana Pendidikan Matematika Universitas Sultan Ageng Tirtayasa. S1 Sistem Informasi Universitas Serang Raya, Serang, 2013. Publikasi di IOP Conference Series: Materials Science and Engineering 337 (1), 012055 dengan Judul Effective production planning for purchased part under long lead time and uncertain demand: MRP Vs demand-driven MRP.

\section{Dr. Heni Pujiastuti, M.Pd.}

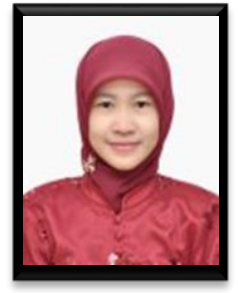

Lahir di Serang, 10 Agustus 1982. Saat ini bekerja sebagai dosen di Jurusan Pendidikan Matematika, Fakultas Keguruan dan Ilmu Pendidikan Universitas Sultan Ageng Tirtayasa (Untirta). Menyelesaikan S1 Pendidikan

Matematika di Universitas Lampung (Unila) Lampung tahun 2005, S2 Pendidikan Matematika di Universitas Pendidikan Indonesia (UPI) Bandung tahun 2008, dan S3 Pendidikan Matematika di UPI tahun 2014. Telah banyak artikel yang diterbitkan dalam jurnal maupun prosiding, salah satunya berjudul Inquiry Cooperation Model for Enhanching Junior High School Students' Mathematical Problem Solving Ability yang dipublikasikan dalam International Journal of Contemporary Educational Research (IJCER), Vol (1), 2014. Publikasi lainnya berjudul Interactive Teaching Materials Based On Scientific Approach: Triangle and Quadrilateral Concepts yang dipublikasikan pada SHS Web of Conferences Volume 42 (2018). Peneliti aktif dalam kegiatan penelitian baik yang didanai Untirta maupun Kemenristekdikti. Beberapa skim penelitian yang pernah didanai Kemenristekdikti diantaranya Hibah Dosen Pemula, Hibah Doktor, Hibah Bersaing, dan Hibah Penelitian Ungulan Perguruan Tinggi. Saat ini peneliti juga tergabung dalam Indonesian Mathematical Society (IndoMS) sebagai Koordinator Wilayah Banten periode 2016-2018. 